\title{
Study of the Mechanical Properties of Natural Rubber Composites with Synthetic Rubber Using Used Cooking Oil as a Softener
}

\author{
Nasruddin ${ }^{*}$ and Tri Susanto \\ Palembang Institute for Industrial Research and Standardization, Ministry of Industry, \\ Jl. Perindustrian II No. 12 Km. 9, Palembang 30152, Indonesia
}

${ }^{*}$ Corresponding author:

email: nas.bppi@gmail.com

Received: January 2, 2019

Accepted: March 12, 2020

DOI: $10.22146 /$ ijc. 42343

\begin{abstract}
This research aims to study the mechanical properties of natural rubber composites with nitrile butadiene rubber and ethylene propylene diene monomer rubber. Composite fillers consisted of kaolin, and softener using used cooking oil. The study was carried out by the method of mastication, vulcanization, and maturation of the compound into rubber vulcanizates. The vulcanization and mastication process is carried out in the open mill. The maturation of the compound into rubber vulcanizates from the results of mastication and vulcanization was carried out using semi-automatic heat press and press at a temperature of $130^{\circ} \mathrm{C} \pm 2{ }^{\circ} \mathrm{C}$ for $17 \mathrm{~min}$. Based on data from testing the mechanical properties of five samples from five formulas, the mechanical properties of composite rubber are affected by the ratio of natural rubber, synthetic rubber, kaolin, and used cooking oil as a softener. The difference in the results of vulcanizates rubber testing of natural rubber composites with synthetic rubber is not only influenced by the ratio of the composite, but also by the degree of cross-linking between the material molecules.
\end{abstract}

Keywords: properties; natural rubber; synthetic rubber; used cooking oil

\section{- INTRODUCTION}

The composite material consists of two or more mixtures, each of which has different mechanical characteristics and properties. Composite materials with different mechanical properties have the advantage of being used as technical goods. Differences in the mechanical properties of materials in a mixture can complement each other to form a mixture that is better than the original material. Polymer matrix composites in the last decade have been widely used for various engineering goods applications in order to improve the mechanical properties of the products produced [1-4].

Natural rubber with the general formula cis-1,4polyisoprene has high double bond and elasticity but is not resistant to heat, and ozone attack [5-6]. According to Linos et al. [7], oxygen attacks can reduce the number of double bonds by cutting the polymer chain on cis-1,4, which causes a biodegradation process that produces carbonyl groups with one-sided aldehydes and ketones. Composite natural rubber with various materials for technical goods needs has various advantages, including its mechanical properties. Composite natural rubber with carbon fill material from several studies can improve the mechanical properties of rubber vulcanization better [8-9].

Natural rubber composites are examples that produce mechanical properties that are better than the original material [10]. Composite natural rubber with various materials for technical goods needs has various advantages, including its mechanical properties. Composite natural rubber with carbon fill material from several studies can improve the mechanical properties of rubber vulcanization better [11-12]. Natural rubber (NR) composites with nitrile butadiene rubber (NBR), and ethylene propylene diene monomer rubber (EPDM) from several studies that have been done can improve ozone resistance [13-14]. Reclaimed rubber composites with styrene butadiene rubber can improve the properties of styrene-butadiene [15-16]. NBR in silica composites, as reinforcement fillers, can improve the dynamic properties of rubber vulcanizates [17-18]. According to $\mathrm{Wu}$ and Tian [19], composites of natural 
rubber, synthetic rubber (SBR, BR, NBR, EPDM, and CR) with kaolin fillers as a substitute for silica can improve properties of rubber vulcanizates better. Composites of SBR, carbon black, and nano clay modified with organo (MMT Closite-20A) can increase the properties of rubber vulcanizates produced [20-21].

Natural rubber composites carried out on this study by adding NBR and EPDM. The added ingredients include silica and kaolin. The added filler aims to improve the tensile strength, modulus, tear strength, abrasion resistance [22-25]. EPDM, as a composite material, has the advantages of heat resistance, ozone resistance, and moisture resistance [26]. Besides, the addition of silica as an active filler can improve the mechanical properties of a rubber vulcanizate. According to Ahmad et al. [27], natural rubber with silica fillers can increase tensile strength, modulus, tear strength, hardness, and cross bond density, and elongation at break. According to Wang and Chen [28], silica is a reinforcing filler that is widely used to improve the mechanical properties of rubber composites. According to Da Costa et al. [29], the addition of silica from rice husk ash on composite rubber can increase the tensile strength and abrasion resistance.

The filler added to the polymer matrix will need to be added to the softener so that it can be evenly distributed. The development of softening materials for vegetable oil-based rubber compounds has been carried out [30]. Vegetable oils have the advantage of being environmentally friendly and renewable. Jatropha oil [3132], and palm oil [33-34] have been used as a softener. Castor oil as a softener to improve the mechanical properties of rubber compounds has been developed [3536]. According to Song [37], palm oil can be used as a softener in the manufacture of rubber compounds.

In this study, natural rubber composites used cooking oil softener from palm oil. Used cooking oil from palm oil in natural rubber composites with synthetic rubber aims to increase the distribution of additives and fillers into natural rubber composite molecules with synthetic rubber. Used cooking oil softener from palm oil contains saturated fatty acids [38]. The addition of used cooking oil as a softener is intended to stretch polymer matrix molecules so that the added ingredients can be distributed evenly. During vulcanization, complex chemical reactions occur between molecular matrix polymers with process materials such as sulfur and other materials [39-40]. This research studies the mechanical properties of rubber vulcanizates from natural rubber composites, synthetic rubber, with filler (silica and kaolin), with softeners from used cooking oil.

\section{- EXPERIMENTAL SECTION}

\section{Materials}

The material used for this study consisted of natural rubber (NR) type SIR-20, and nitrile butadiene rubber (NBR-N.2205), ethylene propylene diene monomer rubber (EPDM), zinc oxide purity 95\% for rubber tire application, stearic acid CAS No: 57-114-4 purity $99 \% \mathrm{~min}$, 2,2,4-trimethyl-1,2-dihydroquinoline (TMQ-RD) TMQ 26780-96-1, pigment yellow 83 (PLPY 83 product code $\mathrm{HRO}_{2}$, chemical class dis azo pigment color Index No: 21108 CAS No: 5567-15-7), silicon dioxide $\left(\mathrm{SiO}_{2}\right)$ CAS No: 112945-52-5 purity 99.8\%, kaolin 400 mesh from Tanjung Pandan Belitung Indonesia, 2-mercaptobenzothiazole (MBTS-CAS: 12078-5), titanium dioxide CAS No: 13463-67-7 with purity 98\%, polyethylene glycol (PEG-4000) CAS No: 2532268-3 purity 99\%, diphenylguanidine (DPG) CAS No: 102-06-7 purity 99\%, used cooking oil (UCO) derived from palm oil as a softener, sulfur CAS No: 7704-34-9 purity $99 \%$, and paraffin wax with a melting point of $37^{\circ} \mathrm{C}\left(99^{\circ} \mathrm{F} ; 310 \mathrm{~K}\right)$.

\section{Instrumentation}

The tools used for this study consisted of rubber mixing mill Model No. XK 160-450 origin China (Mainland), analytical balance capacity of $3.200 \mathrm{~g}$ (Mettler Toledo ME30020), platen rubber vulcanizing press rubber machine Model Number: SKZ401, infrared thermometer (Brand KRISBOW-KW08-280), and molding (equipment for making test samples).

\section{Experimental Design}

Studies on the effects of natural rubber composites and synthetic rubbers were carried out by varying natural rubber (NR) type SIR-20, and nitrile butadiene rubber (NBR-N.2205), ethylene propylene diene rubber 
monomer (EPDM). The ratio of additional ingredients used, such as accelerators, color pigments, activators, fillers, anti-oxidants, anti-ozone, softeners, and conditioned vulcanization. This experiment consisted of five treatments with three replications. Discussion is taken from the average of experiments. The ratio of ingredients used in this study for each formula is shown in Table 1.

\section{Procedure}

\section{Compound preparation}

The natural rubber is ground with an open mill until it becomes soft (15 min). While continuing grinding, nitrile butadiene rubber is added, and at the same time, EPDM is added as well ( $3 \mathrm{~min}$ ), then followed by the addition of titanium oxide until the rubber composite color turns white when pounded for $2 \mathrm{~min}$. The next yellow pigment is added until the rubber composite color turns yellow within 2 min while continuing to add $\mathrm{ZnO}$ and stearic acid for $2 \mathrm{~min}$. Next, silica, paraffin wax, kaolin, PEG, TMQ, and UCO were added together in grinding for $4 \mathrm{~min}$. MBTS and DPG were added together to the rubber mixture with a grinding time of $2 \mathrm{~min}$. Sulfur is added when all the mixture is homogeneous, and

Table 1. Rubber composite formula

\begin{tabular}{lccccc}
\hline \multirow{2}{*}{ Ingredients } & \multicolumn{5}{c}{ Formula } \\
\cline { 2 - 6 } & $\mathrm{A}^{*}$ & $\mathrm{~B}^{*}$ & $\mathrm{C}^{*}$ & $\mathrm{D}^{*}$ & $\mathrm{E}^{*}$ \\
\hline NR-SIR 20 & 100 & 80 & 75 & 75 & 80 \\
NBR & 0 & 10 & 10 & 15 & 20 \\
EPDM & 0 & 10 & 15 & 10 & 0 \\
TiO $_{2}$ & 4.15 & 4.15 & 4.15 & 4.15 & 4.15 \\
Pigment Yellow & 5 & 5 & 5 & 5 & 5 \\
ZnO & 4.75 & 4.75 & 4.75 & 4.75 & 4.75 \\
Stearic Acid & 2.25 & 2.25 & 2.25 & 2.25 & 2.25 \\
Silica & 50.25 & 50.25 & 50.25 & 50.25 & 50.25 \\
Paraffin Wax & 1.25 & 1.25 & 1.25 & 1.25 & 1.25 \\
Kaolin & 4 & 4 & 4 & 4 & 4 \\
UCO & 6.55 & 6.55 & 6.55 & 6.55 & 6.55 \\
MBTS & 1.85 & 1.85 & 1.85 & 1.85 & 1.85 \\
PEG & 2.75 & 2.75 & 2.75 & 2.75 & 2.75 \\
TMQ & 1.25 & 1.25 & 1.25 & 1.25 & 1.25 \\
DPG & 0.95 & 0.95 & 0.95 & 0.95 & 0.95 \\
Sulfur & 2.75 & 2.75 & 2.75 & 2.75 & 2.75 \\
\hline annotation: ${ }^{*}$ phr & & & & &
\end{tabular}

it took 2 min of grinding. The total grinding time was $32 \mathrm{~min}$. The ratio of each ingredient added is shown in Table 1.

\section{Making vulcanizate rubber}

The resulting rubber compound is then placed in a molding tool, then vulcanized at a temperature of $130 \pm$ $2{ }^{\circ} \mathrm{C}$ for $17 \mathrm{~min}$ using a hot press.

\section{Test method}

The five formulas of vulcanizate rubber were tested for parameters as follows the hardness testing before and after aging (ASTM D.2240-15), tensile strength before and after aging (ASTM D.412-16), modulus 300\% (ASTM 412.16), elongation at break (ASTM D.412-16), tear strength (ASTM D.624-00, ra2012), the specific gravity (ASTM D.297-15), abrasion resistance (ASTM D.5963-04, ra2015), compression set, $25 \%$ defl, $70{ }^{\circ} \mathrm{C}$, $22 \mathrm{~h}$ (ASTM D.395-16e1), and abrasion resistance (to ASTM D.5963-04, ra20150).

\section{- RESULTS AND DISCUSSION}

\section{Hardness}

The hardness test of natural rubber composites with synthetic rubber from five formulas (Table 1) shows different results, as shown in Fig. 1. Formula A has the lowest hardness value (73 Shore A) compared to the other formulas ( $B, C, D$, and E). Meanwhile, the highest hardness test result (78 Shore A) is seen in formula D (Fig. 1).

The hardness value of rubber vulcanizates is influenced by the ratio of filler, additives, softeners (Table 1), and the density of bonds between molecules of the material. Other than that fillers material kaolin, and silica, according to their respective, its characteristics influence the rubber vulcanizates hardness. The distribution of additives and fillers to rubber composites (natural rubber and synthetic rubber) is influenced by the softener and bond density between composite molecules. Softener material serves to stretch the bond between the composite rubber molecules so that the added material can be distributed evenly into the composite matrix molecule. The hardness value of rubber 


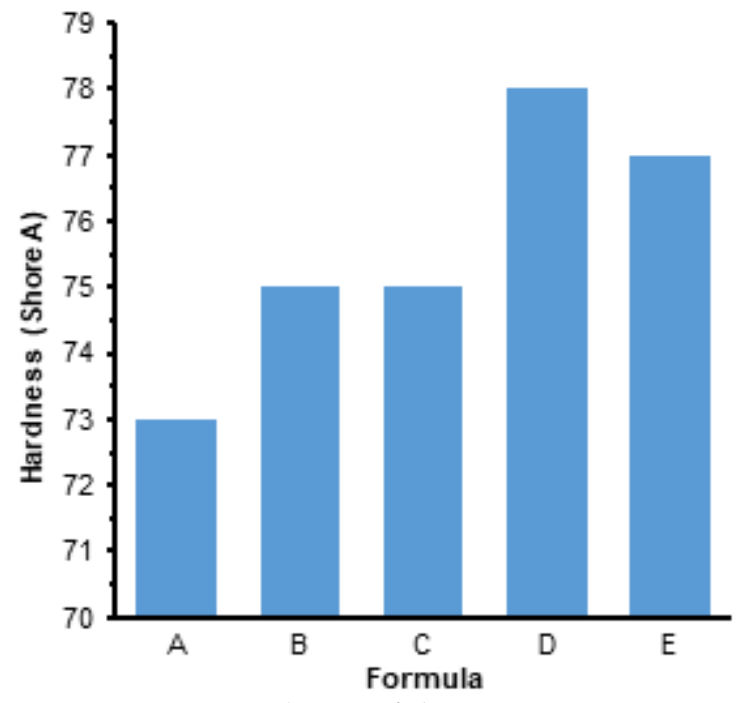

Fig 1. Hardness of the composites

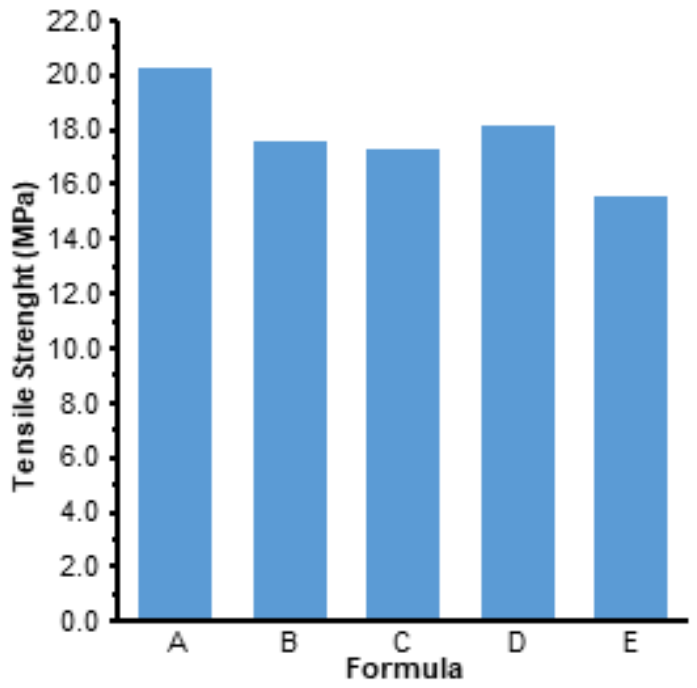

Fig 2. Tensile strength of the composites vulcanizates indirectly illustrates the strength of the bond between a material molecule against pressure by another object [41]. Rubber vulcanizates (Formula A) with kaolin fillers and silica (Table 1) without composition with synthetic rubber (NR and EPDM) hardness value is lower than the value of the hardness of other formulas (Fig. 1). According to Johns and Rao [42], natural rubber that is not mixed with synthetic rubber has a lower hardness value than natural rubber mixed with synthetic rubber.

This shows that the hardness of rubber vulcanizates is influenced by the interaction between natural rubber molecules and synthetic rubber molecules. Additives and fillers with the help of softener to stretch the molecular structure of matrix composites have contributed to the hardness value. In addition, the bonding between molecules of materials and the formation of cross-link reactions by sulfur affect the value of hardness.

\section{Tensile Strength}

The tensile strength describes the strength of a bond between material molecules when pulled in the opposite direction. When a material is pulled, there is a shift between molecules following the direction of withdrawal. The tensile strength of a material is influenced by the type of material used, the ratio of the material, and the process of its formation.

The test data in Fig. 2 shows that the lowest tensile strength value is $15.6 \mathrm{MPa}$ in the formula $\mathrm{E}$. The tensile strength value is influenced by the density of cross bonds between the material molecules. In addition, the tensile strength that is influenced by the ratio of the mixture of natural rubber and synthetic rubber is also influenced by additives, softeners, and fillers (Table 1). The results of the tensile strength test are inversely proportional to the value of the hardness test (Fig. 2). This shows that there is an inverse relationship between the tensile strength with hardness. Tensile strength is related to the degree of elasticity, while hardness is related to the degree of density of the broad unity of the material. Rubber elasticity affects the value of hardness, where the elasticity value of natural rubber is a synthetic rubber. Natural rubber naturally has high elasticity, but its hardness value is low.

The addition of additives to the composite rubber causes interactions between molecules that form strong bonds, which results in increased tensile strength [43]. The addition of additives to natural rubber composites with synthetic rubber, in addition, to increase the density of cross-linking between molecules, also reduces elasticity [44]. Besides, cross-linking density is also influenced by the ratio of material and temperature during the vulcanization process. Natural rubber without composite with synthetic rubber has a higher elasticity (Formula A) compared to composite rubber formulas B, C, D, and E. The differences in elasticity of 
natural rubber and rubber composites cause differences in tensile strength (Fig. 2).

\section{Modulus 300\%}

The modulus test results of $300 \%$ natural rubber and synthetic rubber composites (Fig. 3) show that the modulus values of formulas $\mathrm{B}$ and $\mathrm{C}$ are lower (4.9 MPa) than other formulas (Table 1). Modulus describes the strength needed to stretch the sample to a certain state. According to Dahham et al. [45], the increase in modulus occurs due to an increase in bonds between rubber molecules with additive molecules and filler molecules. According to Chaturvedi et al. [46], differences in modulus values indicate differences in cross-linking density and differences in material ratios.

The combination of several molecules of filler and softener in natural rubber composites with synthetic rubber can improve thermal performance. Improved thermal performance causes a synergistic effect between material molecules [47]. Bonds between material molecules affect the modulus value. The difference in strain strength in products from rubber composite materials, as shown in Fig. 3, is influenced by the strength of the cross-linking between the molecules and the difference in the ratio of natural rubber and synthetic rubber (Table 1).

The difference in the ratio of ingredients causes differences in reactions between molecules and affects the nature of the product formed. Formula $A$, as a

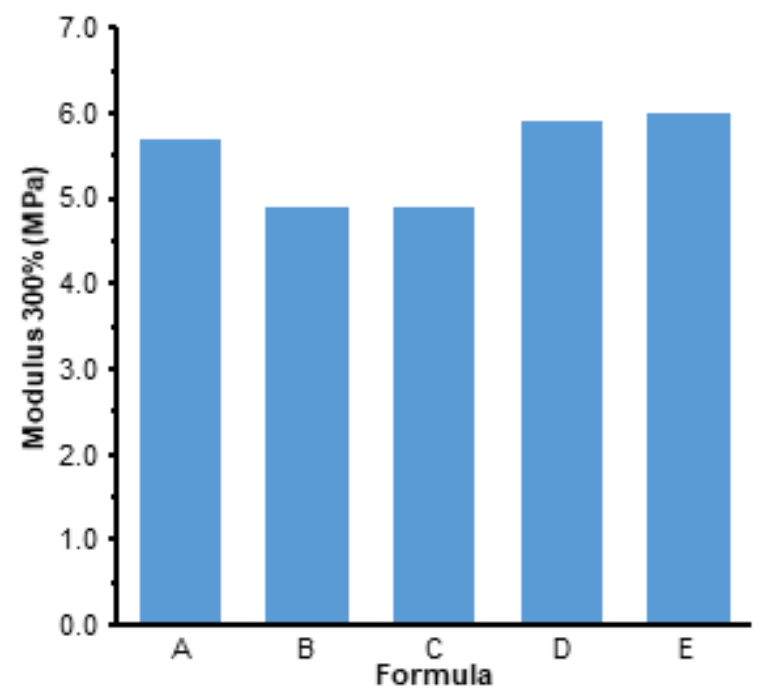

Fig 3. Modulus of the composites comparison formula without addition synthetic rubber, has lower modulus value than formula $\mathrm{D}$, and $\mathrm{E}$. However, the value is higher than formula $\mathrm{B}$ and Formula C. This is caused by differences in the degree of cross-linking formed from each ratio of the formula. The difference in the formation of the degree of cross-linking is influenced by the interaction between the rubber molecule and the filler [48-50].

In addition, fillers (kaolin, and silica) and softeners added to this study had a significant effect on the vulcanization process. Silica, as a reinforcing filler added to rubber composites, aims to improve modulus and other properties [51]. According to Setyowati et al. [52], the addition of active fillers to rubber compounds can improve the properties of rubber vulcanizates better. The difference in modulus values is caused by differences in the cross-linking that is formed from each formula. Silica can gradually increase interactions between fillers and rubber matrices [53]. The speed cross-linking interaction that is formed is influenced by sulfur, additives, fillers, softeners, the ratio of natural rubber, and synthetic rubber used. The difference in the ratio of natural rubber and synthetic rubber (Table 1) determines the difference in modulus values (Fig. 3).

\section{Elongation at Break}

The elongation at break test results of the five formulas (Table 1) shows that there are differences (Fig. 4).

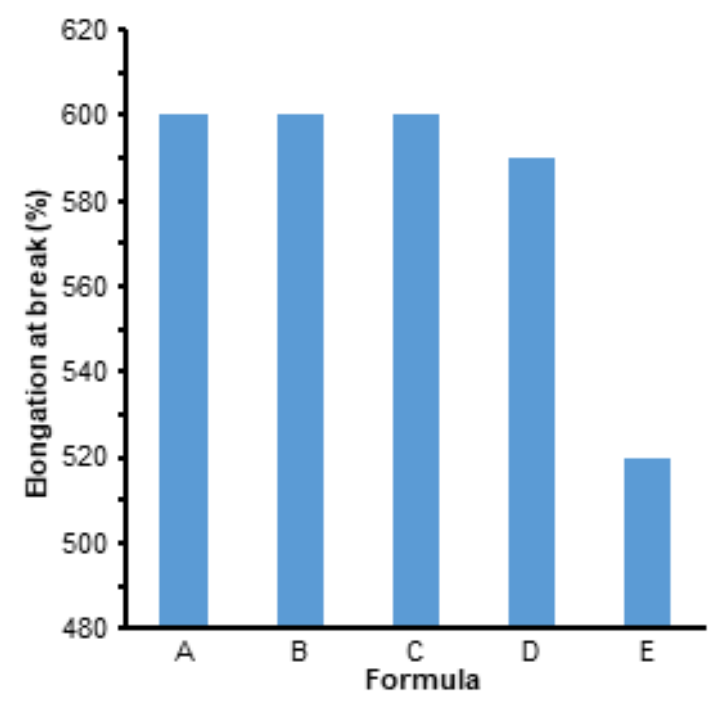

Fig 4. Elongation at break of the composites 
The difference in the value of elongation at break is due to the difference in the ratio of natural rubber with synthetic rubber used. The difference in the ratio of natural rubber and synthetic rubber causes differences in the speed of interaction between the additive, sulfur, and filler molecules. In addition, with the difference in the ratio of natural rubber and synthetic rubber, the softener's performance to stretch the molecules of the composite material follows the ratio of the material used. The elongation at break is directly related to the bond between the molecules, the density of the cross-linking formed, and the degree of elasticity of natural rubber with synthetic rubber composites.

Elongation at break occurs because energy is used to stretch the bond between the vulcanizates molecules to break. Elongation at break is influenced not only by the ratio of natural rubber and synthetic rubber (Table 1) but also by the interaction of fillers and softening that form bonds between the molecular. Additives are added to natural rubber composites with synthetic rubber with the help of sulfur forming a cross-linked network. According to Delchev et al. [54], the addition of active fillers and softeners to rubber composites can increase elongation at break, modulus, hardness, tensile strength.

The interaction between the materials used (Table 1), which forms natural rubber and synthetic rubber composites, greatly determines the value of elongation at break. In addition, the value of elongation at break is also influenced by softening material used to stretch composite molecules. The test results show that, for natural rubber formula $\mathrm{A}$ without synthetic rubber, the elongation at break value is the same as formula $\mathrm{B}$ and formula $\mathrm{C}$, but higher than formula D and formula $\mathrm{E}$ (Fig. 4). For formula $\mathrm{A}$, interactions occur between natural rubber molecules and molecules of additives. For formulas B, C, D, and E, the interactions occur between molecules of natural rubber, synthetic rubber, and additives.

The elongation at break test results for formula $\mathrm{D}$ (590\%) is lower than formulas A, B, C (600\%), but their values are higher than formula $\mathrm{E}(520 \%)$. The ratio of EPDM and NBR in natural rubber molecules affects the bond between molecules of rubber composite compounds. EPDM and NBR at optimal ratios can produce strong bonds because of their interactions with rubber fillers [55]. Increasing the NBR ratio and decreasing the EPDM ratio in rubber composites (Table 1) affects the cross-link density and the elongation at break value. According to Kim et al. [56], the difference in the EPDM ratio of rubber composites can affect breakout extension values. In formulas B and C, NBR and EPDM produce an elongation at break value that is equal to the value of the elongation at break formula $\mathrm{A}$ (Fig. 4). This illustrates, in formulas B and C, the density of bonds between molecules is the same as formula $\mathrm{A}$. For formulas B, C, D, and E, the interaction that occurs is influenced by the speed of the reaction between molecules of natural rubber composites and synthetic rubber. In addition, additives, fillers, softeners, and sulfur are added to accelerate the vulcanization process to form vulcanizate rubber. When viewed from the ratio of natural rubber and synthetic rubber, it affects the value of elongation at break.

\section{Tear Strength}

The tear strength value, as shown in Fig. 5, showed that formula $\mathrm{E}$ is higher $(63.6 \mathrm{kN} / \mathrm{m})$ than other formulas, and formula $\mathrm{D}$ has the lowest tear strength value $(54.8 \mathrm{kN} / \mathrm{m})$. The added softener material (Table 1) affects the bond between the rubber composite molecules. At the same time, the movement of the filler and the additive occupy the rubber composite chamber. The amount of additives and fillers that occupy the space between the rubber composite molecules influences the difference in tear strength values.

Formula $\mathrm{A}$, as a comparison formula without synthetic rubber, has a tear strength value equal to formula B but is lower than formula E (Fig. 5). The difference in the value of tear strength from each formula was caused by the ratio of natural rubber and synthetic rubber, while for the addition of softener material and filler material affected the mechanical properties of rubber, especially against the value of tear strength. Tear strength is directly related to the bonds between molecules, cross-linking, and the level of density of molecules that form rubber vulcanizates. In addition, the ratio of natural rubber and synthetic rubber 


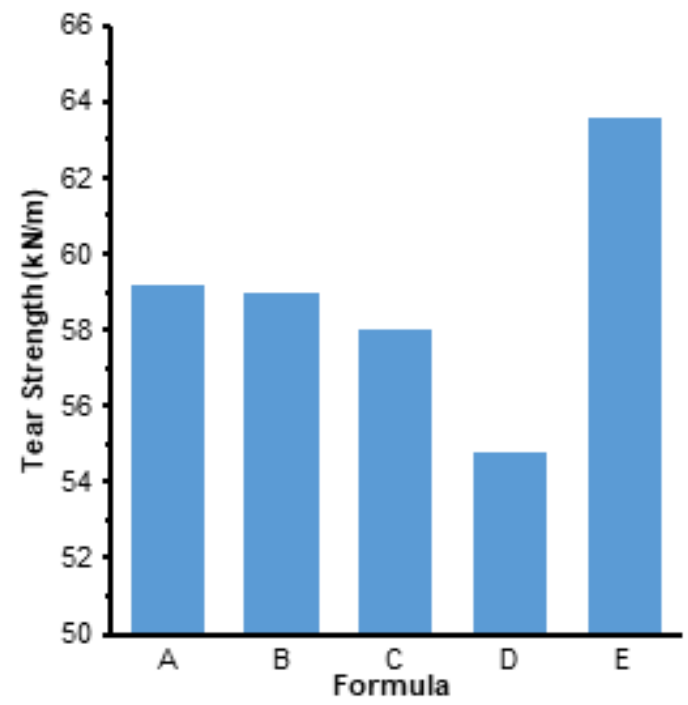

Fig 5. Tear strength of the composites

and fillers greatly determines the binding capacity between molecules, which ultimately determines the nature of the rubber vulcanizates. The ratio of the ingredients added (Table 1) influences the intensity of the polymer chain in the form of bonds. It increases the functional groups associated with the Van der Waals style to the polymer chain in a composite of natural rubber with synthetic rubber.

\section{Specific Gravity}

The results of testing the specific gravity of the five samples before and after aging, as shown in Fig. 6, have a significant difference. The specific gravity value of formula $B$ before aging and after aging is $1.160 \mathrm{~g} / \mathrm{cm}^{3}$, lower than formulas A, C, D, and E. The specific gravity values for formula $\mathrm{E}$ before aging and after aging of 1.18 $\mathrm{g} / \mathrm{cm}^{3}$ are higher than formulas A, B, C and D (Fig. 6). The aging process causes damage to the elastomeric tissue [55]. Elastomeric tissue damage due to an increase in temperature during the aging process. During the aging process, there is a movement of bonds between the material molecules. The movement of bonds between molecules can damage the molecular structure of the material. The occurrence of molecular expansion or constriction due to the aging process depends on the mechanical properties of the ingredients and the ratio of the constituent materials.

The difference in the value of specific gravity is not

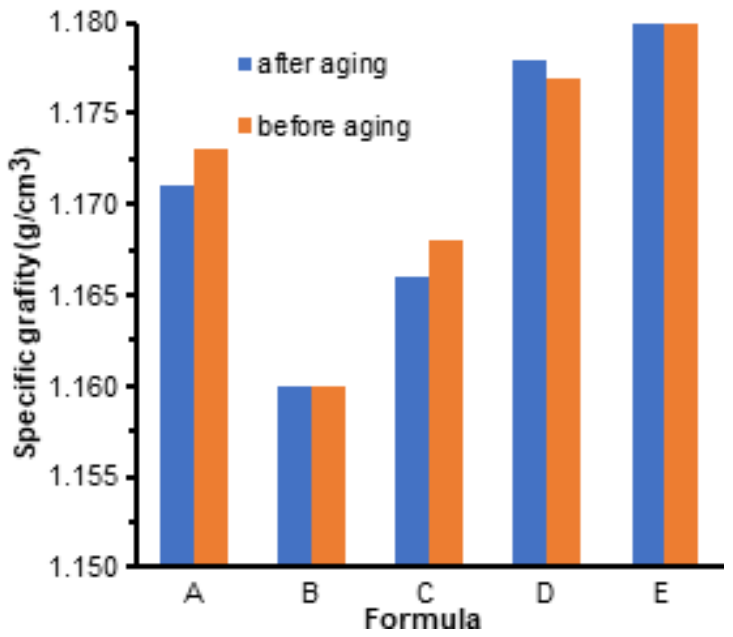

Fig 6. Specific gravity of the composites

only influenced by the level of density between the molecules of the material. However, it is also affected by the compound milling process. The distribution of material into the rubber vulcanizate molecule, the time of vulcanization, and the change in temperature at the time of compound maturation also affect specific gravity.

The ability of softener to stretch the molecular structure of the rubber composite during grinding also influences the speed of the additive and filler to enter the molecular structure of the rubber composite. The speed of distribution of the material into the rubber composite molecule at the time of compound milling and the speed of the vulcanization reaction that forms a threedimensional network have an effect on the density of cross bonds and the level of density of the rubber composite. In addition, differences in material ratios and material types also affect differences in specific gravity values. According to Hashim et al. [57], changes in the value of specific gravity are influenced by the ingredients used. Increasing the specific gravity of rubber can be caused by an increase in cross-link between rubber and filler material, where cross-linking density causes reduced pores formed [15]. The number of pores formed affects molecular density and specific gravity values.

\section{Abrasion Resistance}

Rubber vulcanizates test results for abrasion resistance before and after aging in Fig. 7 show a significant difference. 
Testing after aging is carried out at $70{ }^{\circ} \mathrm{C}$ for $24 \mathrm{~h}$ and aimed to determine the loss of the surface after abrasion. Loss of surface part of rubber vulcanizates occurs due to friction/touch with the object in its path or can be expressed by losing the volume of rubber vulcanizates during friction. The lowest abrasion test results are $169.0 \mathrm{~mm}^{3}$ and $175 \mathrm{~mm}^{3}$ for after aging and before aging in formula $\mathrm{C}$, respectively. Meanwhile, the highest abrasion resistance after aging of $188.2 \mathrm{~mm}^{3}$ was obtained from treatment $\mathrm{A}$. The lowest abrasion resistance before aging is $208.7 \mathrm{~mm}^{3}$ in the formula $\mathrm{E}$ (Fig. 7).

The surface loss of rubber vulcanizates is affected by the cross-linking formed during vulcanization, where the strength of the cross-linking is influenced by the ratio of the material used (Table 1). Abrasion resistance is related to the strength of bonds between molecules characterized by the formation of mono-sulfide and disulfide structures. Sulfur, which forms cross-linking with densities between molecules, determines abrasion resistance [58].

\section{Compression Set}

The results of the compression set test of the five formulas (Table 1) for vulcanizates show significant differences. The lowest compression set test result of $45.3 \%$ was found in formula $\mathrm{A}$, and for the highest test result of $54.91 \%$ was obtained from sample D (Fig. 7). Tests of compression set of rubber vulcanizates were carried out at $25 \%$ defl, the temperature of $70^{\circ} \mathrm{C}$, for $22 \mathrm{~h}$.

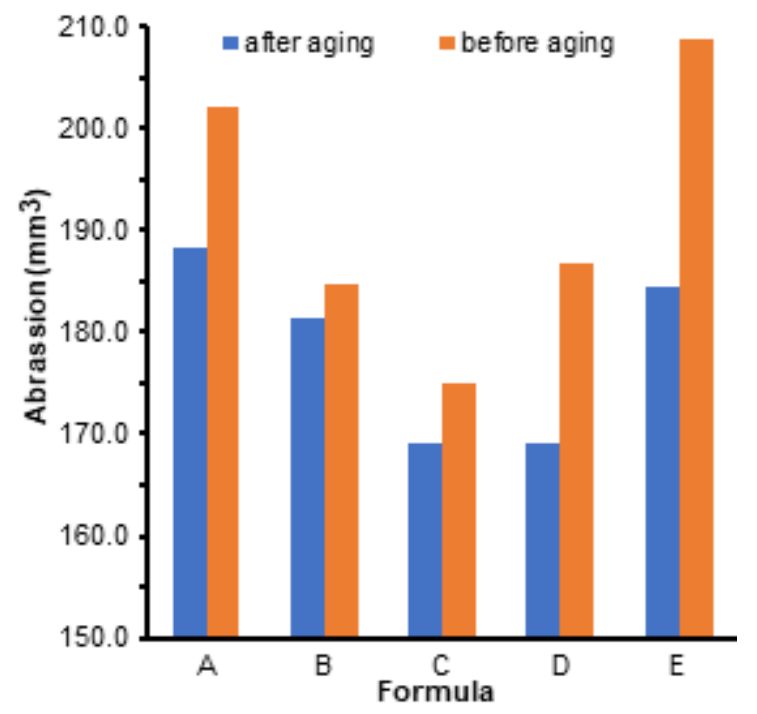

Fig 7. Abrasion resistance of the composites

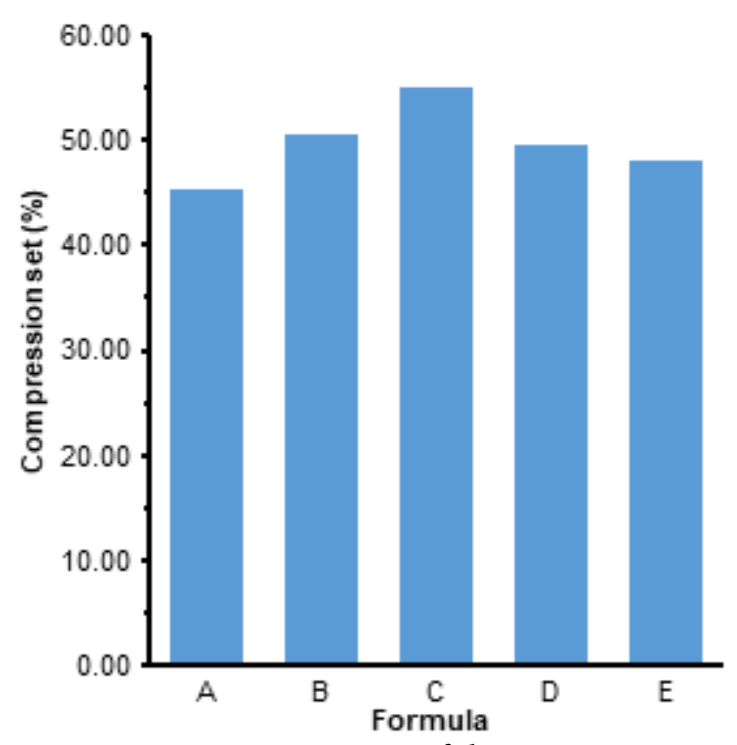

Fig 8. Compression set of the composites

The difference in the value of compression sets is influenced by the interaction between materials and material ratios (Table 1). Based on the test data, Fig. 8 illustrates the bond strength between composite rubber molecules influenced by the strength of the cross-linking formed from the reaction of sulfur with rubber molecules and additives. The strength of cross-linking is influenced by the vulcanization process and the ratio of the material used. The mechanical properties of vulcanization composites are influenced by composite compounds, material distribution, and material homogeneity [59]. Homogeneity and the specific gravity of materials affect the resistance of rubber vulcanizates when under pressure. In addition, the value of the compression set is related to the mass specific gravity, which is illustrated by the values of specific gravity, elongation at break, and other properties.

\section{- CONCLUSION}

The study of natural rubber composites with synthetic rubber (NBR, and EPDM) using used cooking oil softeners has an effect on differences in the mechanical properties of the resulting rubber vulcanizate. The difference in the ratio of natural rubber and synthetic rubber affects the performance of the softener to stretch the molecular structure of the composite material (natural rubber with synthetic rubber) and affects the bond between the molecular, as well as the 
formation of the cross-link reaction by the sulfur. The test results of mechanical properties such as A formula, as a comparative formula without composites with synthetic rubber, have a value of 73 Shore A hardness, which is lower than $\mathrm{B}, \mathrm{C}, \mathrm{D}$, and $\mathrm{E}$ formulas. The tensile strength value of $20.3 \mathrm{MPa}$ is higher than the $\mathrm{B}, \mathrm{C}, \mathrm{D}$, and $\mathrm{E}$ formulas. Modulus $300 \%$ with a value of $5.7 \mathrm{MPa}$ is higher than $\mathrm{B}$, and $\mathrm{C}$ formulas but lower than $\mathrm{D}$, and $\mathrm{E}$ formulas. The Elongation at break with a value of $600 \%$ is the same as $\mathrm{B}$ and $\mathrm{C}$ formulas. However, the value is higher than $\mathrm{D}$, and $\mathrm{E}$ formulas. Tear strength of $59.2 \mathrm{kN} / \mathrm{m}$ is higher than $\mathrm{B}, \mathrm{C}$, and D formulas but lower than $\mathrm{E}$ formula. The specific gravity value before aging of $1.173 \mathrm{~g} / \mathrm{cm}^{3}$, and after aging of $1.171 \mathrm{~g} / \mathrm{cm}^{3}$, is higher than $\mathrm{B}$, and $\mathrm{C}$ formulas, but lower than $\mathrm{D}$, and $\mathrm{E}$ formulas. The abrasion resistance before the aging of $202.2 \mathrm{~mm}^{3}$ is higher than $B$, $\mathrm{C}$, and $\mathrm{D}$ formulas but lower than $\mathrm{E}$ formula. The abrasion resistance after aging of $188.2 \mathrm{~mm}^{3}$ is higher than $\mathrm{B}, \mathrm{C}, \mathrm{D}$, and $\mathrm{E}$ formulas. The compression set with a value of $45.3 \%$ is lower than B, C, D, and E formulas.

\section{- ACKNOWLEDGMENTS}

Thanks to the Head of Palembang Institute for Industrial Research and Standardization for providing research facilities, Director of PT Shima Prima Utama, which has provided information regarding the use of rubber for medical equipment and provides research facilities, and technicians. PT. Shima Prima Utama who has helped research activities. Thank you to Prof. Dr. Ir. Dedik Budianta, MS, who has deigned to correct this manuscript.

\section{- REFERENCES}

[1] Masłowski, M., Miedzianowska, J., and Strzelec, K., 2019, Natural rubber composites filled with crop residues as an alternative to vulcanizates with common fillers, Polymers, 11 (6), 972.

[2] Sawere, B.T., and Igbuku, A.U., 2016, Evaluation of some mechanical properties of composites of natural rubber with egg shell and rice husk, Int. Res. J. Adv. Eng. Sci., 1 (3), 71-75.

[3] Koumoulos E.P., Trompeta, A.F., Santos, R.M., Martins, M., dos Santos, C.M., Iglesias, V., Böhm, R.,
Gong, G., Chiminelli, A., Verpoest, I., Kiekens, P., and Charitidis, C.A., 2019, Research and development in carbon fibers and advanced highperformance composites supply chain in Europe: A roadmap for challenges and the industrial uptake, $J$. Compos. Sci., 3, 86.

[4] Pandian, J.J., and Govindan, T., 2015, Comparative studies on the mechanical properties of natural rubber and natural rubber carbon black composites, IJETCSE, 13 (2), 48-52.

[5] Krishnan, Y., Chandran, S., Usman, N., Smitha, T.R., Parameswaran, P.S., and Prema, K.H., 2015, Processability, mechanical and magnetic studies on natural rubber- ferrite composites, Int. J. Chem. Stud., 3 (1), 15-22.

[6] Yahya, Y.S.R., Azura, A.R., and Ahmad, Z., 2011, Effect of curing systems on thermal degradation behaviour of natural rubber (SMR CV 60), J. Phys. Sci., 22 (2), 1-14.

[7] Linos, A., Berekaa, M.M., Reichelt, R., Keller, U., Schmitt, J., Flemming, H.C., Kroppenstedt, R.M., and Steinbüchel, A., 2000, Biodegradation of cis1,4-polyisoprene rubbers by distinct actinomycetes: Microbial strategies and detailed surface analysis, Appl. Environ. Microbiol., 66 (4), 1639-1645.

[8] Mente, P., Motaung, T.E., and Hlangothi, S.P., 2016, Natural rubber and reclaimed rubber composites-A systematic review, Polym. Sci., 2 (1), 7.

[9] Aguele, F.O., Madufor, C.I., and Adekunle, K.F., 2014, Comparative study of physical properties of polymer composites reinforced with uncarbonised and carbonised coir, Open J. Polym. Chem., 4, 73-82.

[10] Egwaikhide, P.A., Akporhonor, E.E., and Okieimen, F.E., 2007, Effect of coconut fibre filler on the cure characteristics physico-mechanical and swelling properties of natural rubber vulcanisates, Int. J. Phys. Sci., 2 (2), 039-046.

[11] Pornprasit, R., Pornprasit, P., Boonma, P., and Natwichai, J., 2016, Determination of the mechanical properties of rubber by FT-NIR, J. Spectro., 2016, 4024783.

[12] Arayapranee, W., and Rempel, G.L., 2013, Effects of polarity on the filler-rubber interaction and 
properties of silica filled grafted natural rubber composites, J. Polym., 2013, 279529.

[13] Ajam, A.M., Al-Nesrawy, S.H., and Al-Maamori, M., 2016, Effect of reclaim rubber loading on the mechanical properties of SBR composites, Int. J. Chem. Sci., 14 (4), 2439-2449.

[14] Ismail, H., Ahmad, H.S., and Rashid, A.A., 2015, Fatigue, resilience, hardness, and swelling behaviour of natural rubber/recycled acrylonitrile-butadiene rubber (NR/NBRr) blends, Polym. Polym. Compos., 23 (8), 583-588.

[15] Kapgate, B.P., Das, C., Basu, D., Das, A., and Heinrich, G., 2013, Rubber composites based on silane-treated stöber silica and nitrile rubber: Interaction of treated silica with rubber matrix, $J$. Elastomers Plast., 47 (3), 248-261.

[16] Mousavi, M., Arjmand, O., Mostajabi, H., and Shooli, H., 2013, Investigation of physical, mechanical and biodegradation properties of nitrile butadiene rubber by natural polymers and nanosilica particles, AIJRFANS, 5 (1), 110-117.

[17] Suzuki, N., Ito, M., and Ono, S., 2005, Effects of rubber/filler interactions on the structural development and mechanical properties of NBR/Silica composites, J. Appl. Polym. Sci., 95 (1), 74-81.

[18] Singh, R., Shah, M.D., Jain, S.K., Shit, S.C., and Giri, R., 2013, Elastomeric composite: Mechanical and thermal properties of styrene butadiene rubber (SBR) based on carbon black and nanoclay, J. Inf. Knowl. Res. Mech. Eng., 02 (02), 515-521.

[19] Wu, W., and Tian, L., 2013, Formulation and morphology of kaolin-filled rubber composites, Appl. Clay Sci., 80-81, 93-97.

[20] Setyorini, I., and Yuniari, A., 2017, Determination of vulcanization rate constant, crosslink density, and free sulfur content on carbon black filled EPDM, MKKP, 33 (2), 93-98.

[21] Ugbaja, M.I., Onuoha, M.I., Ibeneme, U., Uzochukwu, M.I., Opara, H., and Mbada, I.N., 2016, Swelling and mechanical behaviour of natural rubber vulcanisate filled with leather wastes (buffing dust) and its modeling, Am. J. Appl. Sci. Res., 2 (2), 6-11.
[22] Okele, I.A., Mohammed, F., Agho, B.O., Marut, A.J., and Jekada, J.Z., 2015, Experimental study on particle size and filler loading reinforcement of sugarcane baggase on natural rubber compound, $R R P L, 6$ (4), 155-160.

[23] Aguele, F.O., and Madufor, C.I., 2012, Effects of carbonised coir on physical properties of natural rubber composites, Am. J. Polym. Sci., 2 (3), 28-34.

[24] Mohammed, M.R., and Hadi, A.N., 2012, Effect of egg shells powder on some mechanical and physical properties of natural rubber (NR), Iraqi J. Mech. Mater. Eng., 12 (3), 446-458.

[25] Momoh, F.P., Mamza, P.A.P., Gimba, C.E., and Nkeonye, P., 2016, Morphological trends of modified coconut fibre in natural rubber reinforcement, JETEAS, 7 (4), 167-172.

[26] Ahmed, K., Nizami., S.S., Raza, N.Z., and Shirin, K., 2012, Cure characteristics, mechanical and swelling properties of marble sludge filled EPDM modified chloroprene rubber blends, Adv. Mater. Phys. Chem., 2 (2), 90-97.

[27] Ahmed, K., Nizami, S.S., Raza, N.Z., and Habib, F., 2013, The effect of silica on the properties of marble sludge filled hybrid natural rubber composites, $J$. King Saud Univ. Sci., 25 (4), 331-339.

[28] Wang, J., and Chen, D., 2013, Mechanical properties of natural rubber nanocomposites filled with thermally treated attapulgite, J. Nanomater., 2013, 496584.

[29] Da Costa, H.M., Visconte, L.L.Y., Nunes, R.C.R., and Furtado, C.R.G., 2000, The effect of coupling agent and chemical treatment on rice husk ashfilled natural rubber composites, J. Appl. Polym. Sci., 76, 1019-1027.

[30] Samarth, N.B., and Mahanwar, P.A., 2015, Modified vegetable oil based additives as a future polymeric material-Review, Open J. Org. Polym. Mater., 5, 1-22.

[31] Song, F., Xia, H., Jia, P., Zhang, M., Hu, L., and Zhou, Y., 2018, The effects of epoxidized acrylated castor oil (EACO) on soft poly (vinyl chloride) films as a main plasticizer, Pol. J. Chem. Technol., 20, (4), 13-19. 
[32] Pechurai, W., Chiangta, W., and Tharuen, P., 2015, Effect of vegetable oils as processing aids in SBR compounds, Macromol. Symp., 354 (1), 191-196.

[33] Puspitasari, S., and Cifriadi, A., 2014, Pembuatan bahan pelunak alami untuk kompon karet melalui reaksi hidrogenasi minyak jarak castor, Indonesian J. Nat. Rubb. Res., 32 (1), 56-64.

[34] Nasir, A.N.M., Romli, A.Z., Wahab, M.A., and Abidin, M.H., 2013, Effect of Epoxidized palm oil (EPO) on tensile properties and density of rubber compounding, Adv. Mater. Res., 812, 216-220.

[35] Syamin, Y.M., Azemi, S., and Dzaraini, K., 2017, Evaluation of cooking oil as processing additive for natural rubber, ASEAN J. Sci. Technol. Dev., 34 (1), 17-25.

[36] Puspitasari, S., and Cifriadi, A., 2013, Karakterisasi proses vulkanisasi minyak jarak kastor dan evaluasi mutu hasil faktis cokelat, Buletin RISTRI, 4 (2), 99108.

[37] Song, S.H., 2018, The effect of palm oil-based hybrid oils as green multifunctional oils on the properties of elastomer composites, Polymers, 10 (9), 1045.

[38] Nasruddin, and Susanto, T., 2018, Thermal, morphological and physic-mechanical properties of natural rubber- $\mathrm{CaCO}_{3}$ composites using jatropha oil as softener, MATEC Web Conf., 156, 05016

[39] Aprem, A.S., Thomas, S., Joseph, K., Barkoula, N.M., and Kocsis, J.K., 2003, Sulphur vulcanisation of styrene butadiene rubber using new binary accelerator systems, J. Elastomers Plast., 35 (1), 2955.

[40] Joseph, R., Alex, R., Vinod, V.S., Premalatha, C.K., and Kuriakose, B., 2003, Studies on epoxidized rubber seed oil as plasticizer for acrylonitrile butadiene rubber, J. Appl. Polym. Sci., 89 (3), 668673.

[41] Ramdja, A.F., Febrina, L., and Krisdianto, D., 2010, Pemurnian minyak jelantah menggunakan ampas tebu sebagai adsorben, J. Teknik Kimia, 17 (1), 7-14.

[42] Johns, J., and Rao, V., 2009, Mechanical properties and swelling behavior of cross-linked natural rubber/chitosan blends, Int. J. Polym. Anal. Charact., 14 (6), 508-526.
[43] Mohamad, N., Sharafina, Z.N., Ab Maulod, H.E., Yuhazri, M.Y., and Jeefferie, A.R., 2013, Morphological and mechanical properties of polypropylene/epoxidized natural rubber thermoplastic vulcanizates treated with maleic anhydride-grafted polypropylene, IJAME, 8, 13051315.

[44] Egwaikhide, A.P., Okieimen, F.E., and Lawal, U., 2013, Rheological and mechanical properties of natural rubber compounds filled with carbonized palm kernel husk and carbon black (N330), Sci. J. Chem., 1 (5), 50-55.

[45] Dahham, O.S., Noriman, N.Z., Kahar, A.W.M., Ismail, H., and Sam, S.T., 2015, The Effect of sawdust loading as natural short fiber on NBR/NRL-G compounds, J. Appl. Sci. Agric., 10 (5), 33-39.

[46] Chaturvedi, A., Chaturvedi, S., Rajkumar, K., and Patil, A.S., 2016, Experimental study of natural rubber based shock attenuation device, Int. J. Eng. Stud., 8 (1), 63-71.

[47] Zhang, H., Li, Y., Shou, J.Q., Zhang, Z.Y., Zhao, G.Z., and Liu, Y.Q., 2015, Effect of curing temperature on properties of semi-efficient vulcanized natural rubber, J. Elastomers Plast., 48 (4), 331-339.

[48] Valentini, L., Bon, S.B., Lopez-Manchado, M.A., Verdejo, R., Pappalardo, L., Bolognini, A., Alvino, A., Borsini, S., Berardo, A., and Pugno, N.M., 2016, Synergistic effect of graphene nanoplatelets and carbon black in multifunctional EPDM nanocomposites, Compos. Sci. Technol., 128, 123130.

[49] Karaağaç, B., İnal, M., and Deniz, V., 2011, Predicting optimum cure time of rubber compounds by means of ANFIS, Mater. Des., 35, 833-838.

[50] Alemdar, A., and Sain, M., 2008, Biocomposites from wheat straw nanofibers: Morphology, thermal and mechanical properties, Compos. Sci. Technol., 68 (2), 557-565.

[51] Chuayjuljit, S., Imvittaya, A., Na-Ranong, N., and Potiyaraj, P., 2002, Effects of particle size and amount of carbon black and calcium carbonate on 
curing characteristics and dynamic mechanical properties of natural rubber, JMMM, 12 (1), 51-57.

[52] Setyowati, P., Rahayu, S., and Supriyanto, 2004, Karakteristik karet ebonit yang dibuat dengan berbagai variasi rasio RSS I/Riklim dan jumlah belerang, MKKP, 20 (1), 10-14.

[53] Norhafizah, Z., Noriman, N.Z., Kamarudin, H., Sam, S.T., Ismail, H., Omar, M.F., Ruzaidi, C.M., and Afiratul, A.A., 2015, Properties of ethylene propylene diene monomer/recycled acrylonitrile-butadiene rubber blends (EPDM/rNBR): Effect of the addition of bamboo fillers, Appl. Mech. Mater., 815, 19-23.

[54] Delchev, N., Malinova, P., Mihaylov, M., and Dishovsky, N., 2014, Effect of the modified solid product from waste tyres pyrolysis on the properties of styrene-butadiene rubber based composites, $J$. Chem. Technol. Metall., 49 (6) 525-534.

[55] Neuhaus, C., Lion, A., Johlitz, M., Heuler, P., Barkhoff, M., and Duisen, F., 2017, Fatigue behavior of an elastomer under consideration of ageing effects, Int. J. Fatigue, 104, 72-80.

[56] Kim, Y.S., Kim, Y.T., and Jeon, E.S., 2019, Optimization of accelerator mixing ratio for EPDM rubber grommet to improve mountability using mixture design, Appl. Sci., 9, 2640.

[57] Hashim, F.S., Almaamori, M.H., and Hamood, F.J., 2016, Effect of silica on the mechanical properties of rubber reclaim composite, Int. J. Chem Tech Res., 9 (4), 325-333.

[58] El-Sabbagh, S.H., Ismail, M.N., and Yehia, A.A., 2001, Effect of the curing systems on the fatigue behavior of NR vulcanizates, J. Elastomers Plast., 33, 263-281.

[59] Ateia, E.E., El-Nashar, D.E., Hassan, H.H., and Abd El-Aziz, A.K., 2017, A comparative study of the cure characteristics, mechanical properties and abrasion resistance of silica and carbon black filled NBR/SBR blends, Egypt. J. Chem., 60 (5), 769-777. 